\title{
The Changing Role of Higher Education in Africa: A Historical Reflection
}

\author{
Emnet Tadesse Woldegiorgis ${ }^{1}$ \& Martin Doevenspeck ${ }^{2}$ \\ ${ }^{1}$ Bayreuth International Graduate School of African Studies (BIGSAS), Department of Development Policy and \\ Politics in Africa, Germany \\ ${ }^{2}$ Department of Geography/Bayreuth International Graduate School of African Studies (BIGSAS), Germany \\ Correspondence: Emnet Tadesse Woldegiorgis, Bayreuth International Graduate School of African Studies \\ (BIGSAS), Department of Political Science, University of Bayreuth, Germany. E-mail: \\ emnetadesse@yahoo.com
}

Received: October 10, 2013 Accepted: November 13, 2013 Online Published: November 22, 2013

doi:10.5539/hes.v3n6p35 URL: http://dx.doi.org/10.5539/hes.v3n6p35

\begin{abstract}
This article addresses the changing role of higher education in Africa from the pre-colonial time up to the 1990s. The basic argument is, though higher education institutions are a product of socio-economic and political dynamics of the society in the course of history, these interactions have always been imperfect in Africa since universities did not originally evolve out of social interactions. The introduction of European education during colonial period also did not serve the interests of African societies; instead education was used as a means of extending colonial ideology. After independence, African countries inherited fragile institutions which did not have social legitimacy from the public. The donor-client dependency relationship had inhibited the development of African institutions and the capacity of Africans to develop educational policies which are socially relevant and financially feasible. Thus, higher education institutions in Africa have been carrying out various roles of economic development, Africanization, nation-building, and engines of knowledge economy; at the same time executing foreign roles which have not been owned by African societies.
\end{abstract}

Keywords: higher education, colonization, Africa, reform, policy

\section{Introduction}

Higher education institutions have carried out various responsibilities since the time of their existence. The role they have carried out through time has always been shaped by the continual socio-political and economic dynamics among states, societies and the academic oligarchy (Clark,1983). Higher education policies and reforms have also been a product of historical processes which have been shaped by socio-political and economic contexts of nations. African higher education policy setting and reform measures are also reflections of historical contexts at various times. Thus, the changing role of higher education in Africa could be best understood through analyzing the historical context of the system at large since pre-colonial times. This article analyzes the changing role of higher education in Africa since the pre-colonial setting. To this end, the pre-colonial, colonial and post colonial higher education landscape and policy trends of Africa until the 1990s have been analyzed to describe the changing role of higher education institutions in the content.

\section{Historical Background on Higher Education in Africa}

Though 'modern' higher education systems in Africa are largely a product of European colonial frameworks, various studies indicated that the practice of education at all levels were there in pre-colonial settings of Africa. Prominent scholars in African higher education like Ajayi et al (1996), Assie-Lumumba (2006), and Lulat (2005), extensively documented the genesis of African higher education tracing back to the pyramids of Egypt, the obelisks of Ethiopia, and the Kingdom of Timbuktu. Abjayi et al (1996), for example, have reported the existence of one such academy referred to as the Alexandrian Academy or the Universal Museum Library at Alexandria between 331 and 642 AD. It is also on record that in 859 AD, the Al-Quarawiyyin University was established at Fez in Morocco while the Al-Azhar University at Cairo was established in 970 AD in Egypt (Lulat, 2005). The 2,700 years old tradition of elite education of Ethiopia with an African script called Ge'ez could also be taken as an example of higher form of education in pre - colonial Africa. One of the first African Philosophers 
of the seventeenth century, Zera Yacob of Ethiopia (1599-1692) was also a product of such African foundations (Lange, 1987). Thus, the existence of complex civilizations and higher education learning spaces in Africa prior to the arrival of Europeans indicates that the practice of education at all levels was in place in pre-colonial settings of Africa.

By the end of 1885 after the Berlin Conference on the scramble of Africa, virtually all African continents were under the control of European colonial hegemony. Though, a multitude of European colonizers including Belgium, Germany, the Netherlands, Italy, Portugal, and Spain participated in the process, the British and French played a major role shaping Africa's modern institutions including higher education. Though establishments of primary and secondary educations were there before the First World War (WWI) in colonial Africa, there were only few higher education institutions until the end of the Second World War (WWII). Among the few higher education institutions established before WWI were Fourah Bay College in Freetown, Sierra Leone that was established in 1827 by the Church Missionary Society (CMS) of London as an institution for training African clergymen and schoolmasters; it was the oldest of all established in the Western model (Ridder-Symoens, 1992), but then University of Cape Town (1829) and Stellenbosch University (1866) of South Africa, University of Khartoum (1902), Cairo University(1908), University of Algeria (1909), were established in consecutive years.

After the end of WWI more higher education institutions were established in Africa including Makerere University (1922) of Uganda, Egerton University (1939) of Kenya, University of Ghana (1948), University of Ibadan (1948) of Niagara, Addis Ababa University (1950) of Ethiopia and University of Zimbabwe (1952) came into existence (Damtew, 2003). The establishment of higher education institution in Africa however mainly concentrated on the Northern African countries and South Africa- At the end of the 1960s, for example, Sub Saharan Africa had only 6 universities for a population of 230 million and some countries, including Cape Verde, Djibouti, Gambia, Guinea- Bissau, Seychelles, and Sao Tome and Principe had even no universities at all (Teferra \& Altbach, 2004). Since independence the number of higher education institutions both in public and private sector increased enormously and as of 2009 there are more than 250 public and 420 private higher educations in Africa (World Bank. 2009). Higher education access however, was limited as compared to other regions. In Sub-Saharan Africa, per 100,000 persons, only 162 were Higher education students in 1989 while in Asia it was 645 and in Latin America 1,659 (Ibid). Higher education institutions have always been playing roles given by governments and societies. These roles have been constructed by various agents throughout history and these roles change also through time. The main agent of change in the role of higher education includes governments, societies, international donors and financial institutions, changes in ideology, market force and globalization. In this part, we will look at the changing role of higher education in the pre-colonial and colonial era by looking into the policy trends of the time.

\section{The Changing Role of Higher Education in Pre-Colonial and Colonial Africa}

Learning in pre-colonial Africa was embedded in the cultural setting of the time without having formally established institutions that deal with the production and dissemination of knowledge. In terms of purpose of higher learning and pursuit of knowledge however, indigenous form of learning in pre-colonial Africa bear fruit in building various African civilizations, transferring cultural identity and maintaining coherent way of life in the continent. Moreover, these indigenous forms of learning used to be sources of local autonomy, formation of social elites and institutionalization of culture. Local institutions, including institutions of higher learning, used to be products of societal dynamics continually shaped by the interaction of societal needs. The roles of these institutions of higher learning spaces were constructed by African societies and they predominantly served and were devoted to religious, philosophical, moral, medical and other studies to meet the demands of local people (Abjayi et al, 1996). These indigenous African knowledge systems and learning spaces however, were disrupted, in some cases destroyed and disappeared with the history of wars over slave trades and the coming of European powers as early as $15^{\text {th }}$ century in Africa. Thus, the educational evolution of Africa had been disconnected from its historical past and new exogenous models of institutions, which were not along the African roots, were imposed through colonization.

The coming of these colonial powers and their colonial ideology disconnected the continuity of African indigenous institutions, including education and replaced them with the new Eurocentric institutions through time. Local authorities were compromised and their legitimacy as agents of cultural and institutional continuity started to lose ground as colonial administration gradually penetrated into the social fabrics of African societies. Though at the end of the $19^{\text {th }}$ century European models of education were set up by various colonial administrations, their introduction was not smooth at the beginning of colonization as there were some degrees of suspicion and resistance by Africans. The resistance had manifested itself in a number of ways but most commonly in terms of showing non compliance to take part in European institutions in general and education in 
particular. Various churches for instance were also labeled as places of evil rituals and those attending them used to face social criticism as polluters of the spirits of their ancestors. Assie-Lumumba (2006) for example in her book stated the fact as follow: 'The reaction of Africans in general, when European education was first introduced, was characterized by the overwhelming rejection by leaders and the general population.' (Assie-Lumumba, 2006, p. 30) Rejecting European schools and education of the time was taken as one way of resistance by Africans to be disconnected from their past ways of life and submission to European way of life. Colonial education at the early stage was also communicated through Christian missionaries who came up with new religion, language and culture which were completely foreign to African realities. This situation was understood as a threat to their indigenous culture, religion and institutions. But as the power balance shifted to colonial powers, Europeans managed to create new African elites who passed through their education systems. As it was documented by Lulat (2003), in the later years when few individuals started to access education, they managed to serve within colonial administration and assumed a better position in societies and education started to change their social class. Thus, more and more people started to aspire for European education including higher education as it became the most important avenue toward upwards mobility in the socio-economic and political ladder, and an instrument for self-determination.

According to British philosophy, the main purpose for colonial higher education was to produce the elite required for colonial administration (Ashby, 1961). Higher education was an instrument of facilitating colonial administration instead of enlightening the African societies. As a result access to higher education was extremely limited to few individuals. A World Bank (1991) study reported that at independence less than one-quarter of all professional civil service posts were held by Africans; and only three percent of high school age students received secondary education in British colonies (World Bank, 1991). With all its copper wealth, Zambia had only 100 university graduates and 1000 secondary school graduates in 1961; the university of East Africa (serving Tanzania, Kenya and Uganda) turned out a total of only 99 graduates for a combined population of 23 million in 1960 (Teferra \& Altbach, 2004).

The French colonial power also used higher education as an instrument for their colonial policy of assimilation. The French Assimilation concept was first introduced by a philosopher Chris Talbot in 1837 (Zeleza, 2006). It was based on the idea of expanding French culture to the colonies outside of France in the 19th and 20th century. Natives of these colonies were considered French citizens as long as the culture and customs were adopted. Thus, instead of establishing Higher education institutions in their colonies they sent few Africans to be trained in French universities where they can integrate more to the French culture and way of life. Assie-Lumumba indicated that, the policy basically left the mass of Africans uneducated, and groomed a selected few as modern, co-opted as loyal upholders of French culture and colonial rule, by encouraging them to complete their education in France and to feel more at home in Paris than in Africa (Assie-Lumumba, 2006). For instance between 1952 and 1963, French speaking Africa produced only four graduates in the field of agriculture (Eisemon, 1982). Moreover, most of the students who were sent to universities in France did not return to Africa after completing their studies since they were ideologically brainwashed and forced to believe that French culture and way of life was superior to their own.

The colonial administration of Portuguese resembled the French colonial policy of direct rule and assimilation. Only a few Africans from the emerging local middle class, considered to be assimilated, were actually able to attend universities at the later stage of colonization. Even though the Portuguese were in Africa much earlier than other colonial powers, their efforts to expand education in their colonies were extremely low and no form of higher education existed in Portuguese colonial Africa until the early 1960s. As the illiteracy rate indicated among Africans in 1958, it was close to $100 \%$ in Portuguese colonies of Angola and Mozambique (Ashby, 1961). Though in 1962 Portugal setup two higher education institutions, the University of Luanda and the University of Lourenco Marques, both of which were established to serve the children of Portuguese settlers. Out of a student population of 540 at the University of Lourenco Marques in 1966, for example, only one student was a Mozambican African (Ibid).

The few higher education institutions created in colonies did not even have independent existence as autonomous African institutions instead, they were extensions of universities in the metropolis. When the University of Dakar was established, for instance, a decree from the French Ministry of Education named it as the eighteenth university in the French higher education system (Lulat, 2003). Appointment of teachers, curriculum compositions, programs, and even graduation approval used to be decided by colonial authorities based not on the interests of African societies but on colonial powers. Only those institutions that had attachment to the missionaries were able to get funds and support from colonial powers while the old traditional learning centers and Islamic learning institutions were left behind in the process. As a result, more and more Africans became 
detached from their historic and institutional roots and became structurally dependent on colonial settings. Even though Africa is endowed with the estimated 2,011 languages (Damtew, 2003), these languages have not managed to penetrate into the academia to be media of instruction.

Generally, the objective of establishing Higher education institutions in their colonies was not to address the socio-economic problems of Africa; instead it was basically to facilitate the smooth running of their colonial administration. The programs, courses and trainings were selected based on colonial interests detaching them from their historical past and to accept colonial institutions. African traditional learning spaces, local institutions, languages, religions, and cultures were portrayed as backward and uncivilized by colonial powers as a pretext for their colonial agenda as the only way to become civilized was to learn how to speak colonial language and accept European culture. Though few higher education institutions were established in Africa during colonial times, the programs were not relevant for the needs of Africans of the time and they basically trained extremely few individuals. African people did not own these institutions and they were seen as instruments of domination and colonization instead of academic and scientific environments. The introduction of European model of higher education, therefore, is not a product of a long history of cultural evolution which constructed itself out of African social dynamics; instead, it is a product of European colonial imposition which does not have historical attachments to the African past.

\subsection{The Changing Role of Higher Education in Africa in 1960s And 1970s}

Though most African countries have managed to get political independence since 1960s, achieving autonomy over colonial institutions was not easy at the early stages of independence. The new African governments inherited colonial institutions which did not have the trust from the public. These institutions were seen as instruments of domination and operation; and they were not accepted as African institutions for a long time even after independence (Eicher, 1973). At the time of independence there were few trained African personnel to take over colonial institutions including higher education institutions. Thus, in this process of transformation from colonial to independence, higher education institutions in Africa shouldered multiple responsibilities as agents of economic growth, creating Africa identity and nation building in the 1960s and '70s.

\subsubsection{The Role as Agent of Development}

Burton Clark (1983) in his analysis on the role of higher education in a society presupposes that the role of higher education and its policy evolves through time with the continuous interaction among the state, the academic oligarchy and the society (the market) representing the demands that society places upon its higher education system (Clark, 1983). In Africa, however, these interactions have always been imperfect since universities did not originally evolve out of the interaction of the aforementioned three; instead they were imposed institutions through the most unwelcomed ideology called colonialism. Thus, the roles of higher education institutions in Africa after independence were not constructed out of social interaction among the society, the state and the academic oligarchy; instead they were a product of government policies to address the challenges of colonial artifact imposed on African societies.

The 1960s and '70s higher education policy of most post independent Africa were defined within the framework of national strategies of development that were adopted in post-colonial Africa. The policies of the time were engaged in the process of decolonization, seeking to redress colonial injustices, and undertaking effective means to achieve socio-economic development (World Bank, 1991). Higher education institutions of the time were also perceived as tools of socio-economic development and political transformation in post colonial Africa to fulfill the role of training professionals, promoting access, extending the frontiers of knowledge, and serving the national economy.

This was the time when the economic theory of Adam Smith, that explains the nexus between human capital and economic development became popular in the field of education. The theory basically asserts that there is a direct correlation between individuals productivity and their level of education and investing on formal education has a cumulative effect of both individual and societal development (Bloom, David, \& Chan, 2005). This human capital theory was convincing enough for most African nationalists and academic elites of the time to articulate national policy directions in favor-of higher education. The United Nations also declared 1960s as the 'development decade' recognizing the importance of education for the development of Africa. Up-on the recommendation of the United Nation, the first regional meeting of African Heads of State and Government on higher education was also held on May 1961 in Addis Ababa followed by the 1962 conference of African universities leaders held in Tananarive, Madagascar (Yesufu, 1973). These conferences clearly affirmed that African governments should take higher education institutions as their major partner for economic growth. More conferences were held in Ghana, Khartoum and Addis Ababa. The conferences of either general or 
specialized nature set about determining Africa's objectives, priorities and the wherewithal, which were intended, so it seemed, to launch the continent into the blissful orbit of social reconstruction and economic affluence. Education naturally received high priority as the notion of associating higher education institutions as instruments of economic growth and ways out of poverty prevailed in the policy documents of most African countries in 1960s and '70s (Aina, 1994).

\subsubsection{The Role as Agent of Africanization}

Apart from being considered as agents of development, the policies of postcolonial Africa conceived higher education institutions of the time as instruments for creating African identity within colonial institutions. . Africanization was understood as upholding African aspirations, descent, cultural heritage, and identity. Malegapuru William Makgoba defined Africanization as "the process or vehicle for defining, interpreting, promoting and transmitting African thought, philosophy, identity, and culture. It encompasses an African mind-set shift from the European to an African paradigm." (Makgoba, 1997, p. 203). This process of creating African institutions was termed as Africanization. The premise for Africanization was the fact that Post colonial institutions including universities were products of European colonial settings which did not represent the needs, interests and values of African people. The curricula, courses and academic orientations of African higher education institutions were not in accordance with the demands of the continent (Ki-Zerbo, 1973). Moreover, almost all academic staffs teaching in these universities were non Africans. Thus, higher education institutions were provided the role not only of training individuals to replace European professors, but also to prepare African workforce that replace Europeans in other institutions.

Just like the development universities of the 1960s, Africanization had also been on regional policy agenda in 1970s. Ten years after the Tananarive conference, there was another workshop organized in Accra in 1973 by the Association of African Universities (AAU). In this conference various African universities leaders and policymakers participated in discussing about the role of African higher education institutions for building African identity and nation. The central purpose of the Workshop was to discover and fulfill an African identity in independent Africa. On their final document "Creating the African University: Emerging issues in the 1970s" (Yesufu, 1973), they agreed to work in coordination to overcome intellectual dependency, through the hastening of Africanization of staff and curriculum reform. As part of the Africanization process, therefore, new national universities were created in a number of African countries with diversified curriculum and institution types markedly different from colonial universities. Some of these universities were Ahmadu Bello University in Nigeria, University of Science and Technology in Ghana, University of Dares Salaam and University of Nairobi (Aina, 1994). The proportion of African teaching staff has risen from 64 percent in 1978-79 to 84 percent in 1986-87. Curricula were also revised to incorporate national content and interests, and graduate training programs were also revised to incorporate national content and interests. Graduate output in the region has risen impressively from 17,000 in 1970 to 83,000 in 1987 (Saint, 1992).

Africanization was popular among African nationalists in the sense of retaining ownership and reclaiming colonial institutions in the 1960s and 1970s (Ki-Zerbo, 1973). The political commitment to localize not only universities but also other public institutions was quite high. At the same time Africanization was not also far from criticism as Afrocentric project that may end Africa in isolation from the rest of the world (Bankole, 2006). Implementing Africanization in higher education institutions was not even easy because of the universal character of knowledge and universities. Scientific knowledge by its nature has universal character which is replicable and used for human progress despite cultural boundaries. Replacing all European professors with African intellectuals and detaching African universities from their European origin through program and curriculum reforms in some cases might lead to intellectual isolation. There was considerable pessimism about the prospect of deviating from European models of higher education since European models have been the source of modern higher education institutions in most parts of the world. As African universities tend to establish more international collaborations with other knowledge nodes across the world, instead of localizing their curricula they would also be tempted to internationalize them.

The process of Africanization of universities as an Afrocenteric process did not last long as African universities started even to engage more and more with European universities in research and scholarship. Those Africans who were replacing European professors were also trained either in European universities or by European professors in Africa. Thus, instead of Africanization the policy trend basically reshaped to another concept called 'contextualization'. The idea of contextualization basically means that higher education institutions may not necessarily move from their historical colonial roots, but within the framework of colonial higher education system their relevance should be contextualized along with the needs of the society (Eicher, 1973). Contextualization basically implies that there is nothing wrong with having European models of higher 
education but what is missing is African knowledge.

Thus, African higher education institutions should do more research on African problems if possible in collaboration with the rest of the world. Research was taken as the main instrument of the contextualization process. Universities were encouraged to do research to address African challenges alongside their teaching responsibilities (Eicher, 1973). Local knowledge intended to be generated through research and then communicated to the public through teaching and publications. This idea of adapting research in the teaching process was taken from the experience of American universities. The partial move from the colonial European model to the American model of linking research and teaching were welcomed by most university managements of Africa. American model however is not really American if we look at it from a historical perspective since the origin of it is in Germany in the early nineteenth century with the Humboldtian model that established a dynamic, dialectical, and mutually reinforcing relationship between teaching and research (Ajayi et al, 1996).

\subsubsection{The Role as Agent of Nation-Building}

In post independent Africa, the role of higher education was not only confined to the social responsibilities of teaching, learning and research but unlike universities in Europe they were also carrying out the responsibilities of nation-building. The newly emerging postcolonial African states inherited weak institutions with poor legitimacy from the public and artificial boundaries with barely shared common heritages that could bind the society together (Seepe, 2004). Thus, African governments were trying to reconstruct African identity through creating strong African institutions which could carry the sense of nationalism among the public.

Nation-building requires a meritocratic bureaucracy in order to make the African institutions to function properly. In this sense, universities were pushed to the limit to create a large middle-class (Accountants, teachers, doctors, technicians, engineers, etc) which is believed to be very important to nation-building (Yesufu, 1973). The nation-building effort was also coupled with the Pan African movement of the 1960s. Both African educated elites and governments were inspired by a bigger nationalistic thought which later led to the establishment of Organization of African Unity (OAU) on 25 May 1963 in Addis Ababa. The early year graduates of African Universities and western trained African academics were the intellectual bases of African nationalism (Seepe, 2004). Generally the higher education policy trend of 1960s and 1970s Africa were hooked in multifaceted social, economic and political responsibilities of economic growth, preserving African identity and nation building.

\subsection{Period of Crisis-1980s}

Having been praised in the 1960s as agents of development, social mobilization, and nation-building, most African universities started tumbling down under the pressures of deteriorating socio-political and economic conditions of 1980s. African economic condition started to crumble when the continent could not managed to penetrate into the global market with weak bargaining power in international trade (Ravenhill, 1986). In 1970s agricultural output in 39 African countries declined from 2.3 to 1.3 percent on average. In 1970s total output in Agriculture sector grew only 1.3 percent a year whiles the number of the population was still growing (World Bank, 1998, 1998). This was even aggravated by stagnant or low production of agricultural products which could not go with the rising number of population. Between 1985 and 1990, Africa had the highest population growth rate of 3.1 percent as compared to 2.34 percent in South Asia, 2.09 percent in Latin America, 0.23 percent in Europe, 0.90 percent in the United States, and 0.70 percent in Canada (Atteh, 1996). Weak international trade led to low foreign currency reserve, deficiency in public revenue, and later led to a state of economic crisis in Africa. The political bureaucracy at the early stage of independence in most countries was not strong enough to deal with such macro level crisis as widespread corruption, administrative and technical inefficiencies became apparent in states administrations.

It was in this period that the higher education sector in Africa faced challenges of inadequate finance and funding. The increasing number of student population which demanded higher education on the one hand and the financial crisis on the other eventually led higher education institutions in Africa to overburden their role. Overall higher education student enrollment in Africa increased from an estimated total of 181,000 in 1975, to over 600,000 by 1980 and the number doubled again in a decade, to 1,750,000 by 1995 (World Bank, 2009). This led to inadequate facilities and infrastructures, problems of quality and relevance, limited capacity of teaching and research, critical shortage of faculty, and huge brain drain. To alleviate the economic crisis and financial constraints of the time, African governments heavily relied more and more on borrowing money from the international financial institutions to keep their public sector operational which led to the escalation of a huge debt crisis in the 1980s (Ravenhill, 1986). Africa became one of the most indebted continents in the world in 1980s. The total debt of Africa as a whole was about $\$ 300$ billion, with 45 percent of debt servicing in 1980s (World Bank, 1999). This external dependence for financial sources also made most African governments to 
compromise their sovereignty of making their own public policies including higher education. International loans and development supports go with preconditions and these presuppose policy prescriptions which may not be in line with the interests of the recipient countries. International institutions mainly IMF and the WB started to interfere in these countries through Structural Adjustment Programs (SAPs) and stabilization programs. A variety of SAPs were introduced in the 1980s and 1990s to address the economic and social crises of the time.

African governments were advised by IMF and the World Bank to cut their public funding of higher education and focus on primary and secondary education. The World Bank also shifted its policy towards financing primary education on the belief that the rate of return of primary and secondary education is greater than higher education (Bloom, David, \& Chan, 2005). Other international donors also followed the footsteps of the World Bank which crippled the development of higher education in Africa (World Bank, 1988). The donor-client dependency relationship had inhibited the development of African institutions and the capacity of Africans to develop educational policies which were socially relevant and financially feasible. Thus African higher education institutions in 1980s had a marginalized role in African societies as they were deprived of both international and domestic supports.

\section{Changes in the Role of African Higher Education in 1990s}

African economy started to show remarkable improvement as of mid-1990s as the continent began slowly integrating into the global economy with rapidly increasing global demand for raw material exported from Africa and increasing macroeconomic stability in most African countries. Africa's economic ties were gradually expanded to include the newly immerged Asia market as most Asian countries were experiencing economic boom since the 1990s (Mckinsey\&Company, 2010). The various trade related reforms which addressed market imperfections and trade barriers also helped African countries to be part of international trade deals. The significant redaction in recurrent political crisis and civil wars in the continent have significantly improved the business climates in the continent. The annual flow of Foreign Direct Investment into Africa, relative to GDP, increased from $\$ 9$ billion in 1990s to $\$ 62$ billion in 2000s (World Bank, 2009). As the economy started to grow, not only new demands for trained man power but also new forms of training that meet the expectation of the new economy was also expected from higher education institutions. This basically changed the role of African higher education in the society. African higher education institutions started to assume the role of being agents of knowledge based economy in an increasingly knowledge intensive economic system in which Africa started to play a role.

\subsection{Re-Positioning the Role of Higher Education}

As we have seen in the previous section, the general understanding of the 1980s on the private and social return of education was on assertion that primary and secondary educations have more social return than higher education (Psacharopoulos, 1985). The World Bank on its Education Sector Working Papers of both 1974 and 1980 also clearly indicated that priority should be given to primary and secondary education (World Bank,1980). Since mid -1990s however, researchers started to come up with new findings stating that the rate of return for higher education is actually higher than it was estimated (Bloom, David, \& Chan, 2005). The new studies on social return of higher education have indicated that a one year increase on average higher education levels would raise annual GDP growth in Sub-Saharan African countries by 0.39 percent and increase African GDP per capita by 12 percent (Ibid). Empirical evidence also supported the view that 'capacity to mobilize knowledge and use it to the full' determines the pace of growth of knowledge economies in OECD countries (OECD, 2000). Moreover, on the practical level the new economic growth in Africa and its integration to the global economy, the acceleration of technology and new production methods, have demanded highly trained personnel to keep the momentum of the economy.

Thus, the role of higher education institutions in knowledge production was recognized as one of the most important means for knowledge economy in the 1990s. African higher education institutions have repositioned their role once again to be engines of economic growth and development since the mid-1990s. The World Bank, the major development partner of higher education in Africa, has also changed its development policy in favor of higher education in Africa. Since the end of the 1980s, the World Bank published consecutive reports in 1988, 1994, and 1998 and 2002 reaffirming the significant role of higher education and in the current knowledge economy. Thus, as knowledge becomes central to the economy, so too does higher education, since as Burton Clark wrote almost three decades earlier, "for as long as higher education has been formally organized, it has been a social structure for the control of advanced knowledge." (Clark, 1983, p. 11)

Acknowledging the urgency of strengthening their higher education sector, African governments have also started to increase the amount of public funding allocated to higher education. The share of higher education in 
public expenditure on education in 1990 on a study made on 39 African countries showed a double increase of 21.2 percent as compared to the 1970s. On average, Sub-Saharan countries spent 18.2 percent of government budgets on education 20 percent of which went to higher education in 2000 (World Bank, 2009). Various kinds of higher education reforms; related to finance, management and governance, research and development, leadership and autonomy; have also been made since the 1990s to bring the higher education sector of Africa on board for economic growth and development. This has been witnessed in Ethiopia, Ghana, Kenya, Uganda, Tanzania Cameroon, Côte d'Ivoire, Egypt and Republic of South Africa (Seepe, 2004). Thus, higher education institutions gradually assumed their role as players in economic growth and development of African nations, and re-positioned themselves as players in a knowledge driven economy through training skilled man power for the newly emerging economic sectors, through extensive collaboration in researches with other European and American universities especially in agriculture and technology, through industry linkage and engaging in various forms of community services.

\subsection{Re-Aligning the Relevance of Higher Education to the Market}

Higher education reforms have in most cases been oriented along the demands of stakeholders (the state, students, employers etc), the dominant ideology and context of the time. The responsiveness of the sector is also determined by the urgency of these demands and the hegemonic power which imposed it. Since independence, African governments have been playing a major role of not only constructing roles for higher education but also of production and distribution of resources, financing of higher education and employing graduates. As a result, higher education institutions were largely responsive to government demands as private sectors were either weak or non-existent. Re-alignment of the higher education relevance to new demands from the private sector, however, became necessary as of the 1990s in order to respond to changes in the production and employment market. The gradual expansion of the private sector, the coming of international companies and foreign direct investments posed additional roles on higher education institutions to be responsive not only to governments but also to the new demands from private sectors.

Global competitiveness also put pressure on higher education institutions to be relevant not only for national demands but also international market forces. African universities and governments have recognized the natures of skills required in the newly growing global economies and the private sectors are different from the old traditional ones. Thus, in post 1990s many African countries restructured their university curricula and training programs to meet market requirements and adopt entrepreneurial spirit (World Bank, 2009). The traditional model of public universities with its one-tier program structure had proven to be expensive and not relevant as to the new market demands of Africa. The new market largely needs graduates that are trained in diverse programs on more of practical rather than theoretical levels and ready to engage in the labor force with short period of time. In order to accommodate new demands, African higher education systems moved from one-tiered mono systems to diversified dual systems - incorporating both private and non-university institutions like colleges, vocational institutions and training centers. Thus, private colleges, universities, and professional institutes were brought on board in the process of expanding access and their numbers have been growing at a far faster rate than public ones since the 1990s. There were only about 20 private higher education institutions in Africa in 1990 but this number exploded to 468 in 2007 accounting for 24 percent of enrollment increase in the region (Varghese, 2009). Though the numbers have always been fluctuating because of regulations from governments and market competition, these are the top African countries which have large numbers of private institutions; South Africa (79), Ethiopia (60), Senegal (41), Democratic Republic of Congo (39), Nigeria, (24), Benin (27), Ghana (25), Uganda (23), Sudan 22, Togo 22 (Ibid).

The introduction of private sectors somehow created some sort of division of role between public and private higher education institutions. On the one hand public institutions focusing on science and technology, research and development, established more campuses in rural areas, and focusing on graduate programs; and on the other private institutions established themselves on urban areas focusing more on humanities and social sciences and mainly undergraduate programs. Along with the issue of expanding access, however, concern over equity and quality of higher education provision became policy concerns of African higher education landscape since the 1990s. Equity in terms of access has become an issue when higher education provision slowly moved from extremely elite -based to somehow generously expanded, if not mass higher education in Africa. Concerns over equity have been expressed on various policy trends in terms of gender, urban vs. rural, financial abilities, geographic and regional locations and ethnic lines. Basically the introduction of private higher education somehow partly addressed some of these concerns as for example private institutions absorb more female students as compared to public. Since the introduction of private higher education institutions, the number of female students increased in higher education participation; for instance in Kenya as of the introduction of 
private institutions female participation rose from 32.2 percent to 54.5 percent in 2002 (Varghese, 2009). Among the reasons mentioned by researchers in the area are the low admission requirement and flexible program schedule in the private institutions are the major factors that attract more women applicants.

As the private universities also focused on urban areas and attracted students who can pay tuitions, African governments shifted their public investment a bit towards rural areas and started to provide student loans and scholarships for those who cannot afford. Ethiopia, for example, constructed 21 new public universities across different geographic areas mainly in rural settings since 1994. Despite these efforts to address the concern of equity, however, the problem of equity still exists in Africa but is no more outside the higher education policy concern and priority of African governments. As access to higher education gradually expanded with the coming of private higher education institutions which are outside of the public higher education policy setting, the concern for quality and relevance of their programs became also an issue since mid-1990s in Africa. The fact that private providers are profit-oriented institutions raised some concerns on the level of their commitment to provide relevant and quality education for the public. Stakeholders - students, parents, employers - demanded some sort of guarantee from private providers on the quality of their higher education. Though the major concern has been on private higher education, public universities have also been the subject of quality control as public universities are expected to be competitive at international rankings setting national benchmarks linked to world-class standards.

\section{Conclusions}

Even though higher education in pre-colonial African setting was not recognized and documented, the existence of various civilizations and cultural continuity indicates the existence of learning spaces prior to the coming of European powers in the region. Such learning spaces played a significant role in communicating African heritages, civilization and way of life through generations. These indigenous African knowledge systems and learning spaces however were interrupted by the coming of colonization which deprived African institutions of their historical roots. European higher education institutions in colonial Africa were not created to meet the needs of African societies of the time instead they were instruments of executing colonial agendas in Africa. Thus, as of independence the new African governments inherited institutions which did not have local autonomies and did not reflect African interests. Higher education institution then shouldered multiple responsibilities to play role as agents of development; preserving African identity and nation building. These roles of African higher education were however interrupted by the economic crisis of the 1980s which made higher education institutions the most unfavored sector by both international financial institutions and African governments. The economic improvement of most African countries in the 1990s however changed the higher education landscape of Africa. The growth of African economy, the popularity of liberal and knowledge-based economy pushed African governments and international financial institutions to reconsider the role of higher education in the economic development of African countries; this led to the re-positioning and re-alignment of the sector once again as a significant player in African societies. This article tried to give a perspective on how the role of higher education has evolved through time in Africa which still needs to be debated and further investigated.

\section{References}

Aina, T. A. (1994). Quality and Relevance: African Universities in the 21st Century. Accra: Association of African Universities.

Ajayi, J., Lameck, K., Goma, G., \& Johnson, A. (1996). The African Experience with Higher Education, Accra: The Association of African Universities. Athens: Ohio University Press.

Artadi, E. A.-I.-M. (2003). Artadi, E. V., an The Economic Tragedy of the XXth Century: Growth in Africa. NBER working paper No.9865. Cambridge, MA: National Bureau of Economic Research.

Ashby, E. (1961). Patterns of universities in non-European societies. London. London: University of London School of Oriental and African studies.

Assié-Lumumba, N. (1993). Higher Education in Francophone Africa: Assessment of the Potential of the Traditional Universities and Alternatives for Development. Washington, DC: World Bank.

Assie-Lumumba, N. T. (2006). Higher Education in Africa. Crises, Reforms and Transformation. Dakar: CODESRIA.

Atteh, S. O. (1996). The Crisis in Higher Education in Africa. A Journal of Opinion: African Higher Education, 24(1), 36-42.

Bloom, D. C., David, \& Chan, K. (2005). Higher Education and Economic Development in Africa. Washington, 
D.C.: World Bank.

Clark, B. (1983). The Higher Education System: Academic Organization in a Crossnational Perspective. Berkeley: University of California Press. http://dx.doi.org/10.1007/BF00140275

Damtew, T. (2003). African Higher Education: An International Reference Handbook. Indiana: Indiana University Press.

Eicher, C. K. (1973). Overcoming Intelectual Dependence. In T. Yesufu, Creating the African University: Emerging Issues in the 1970s (pp. 27-34). London: Oxford University Press.

Eisemon, T. D. (1982). Transplantation of science to anglophone and francophone Africa. Science and Public Poliy, 12(4), 191-192.

Gondwe, M., \& Walenkamp, J. (2011). Alignment of higher professional education with the needs of the local labour market: The Case of Ghana. The Hague: NUFFIC.

Hinchliffe, K. (1987). Higher education in Sub-Saharan Africa. London: Croom Helm: Croom Helm.

Ki-Zerbo, J. (1973). Africanization of Higher education Curriculum. In T. Yesufu, Creating the African University (pp. 11-20). London: Oxford University Press.

Lange, W. (1987). The Source of African Philosophy: The Ethiopian Philosophy of Man by Claude Sumner. The International Journal of African Historical Studies, 20(4), 734-735. http://dx.doi.org/10.2307/219665

Lulat, Y. G. (2003). The development of higher education in Africa: A historical survey. In D. T. Altbach, \& D. T. Altbach (Eds.), African higher education: An international reference handbook (pp. 15-31). Bloomington: Indiana University Press.

Lulat, Y. G.-M. (2005). A History of African Higher Education from Antiquity to the Present. Westport CT: Praeger Publishers.

Mckinsey, \& Company. (2010, June). What's driving Africa's growth. Retrieved September 12, 2013, from http://www.mckinsey.com/insights/economic_studies/whats_driving_africas_growth

OECD. (2000). Education at a Glance: OECD INDICATORS. Cedex 16, France: OECD Publications Service. http://dx.doi.org/10.1787/eag-2000-en

Psacharopoulos, G. (1985). Returns to Education: A Further International Update and Implications. Journal of Human Resources, 20(4), 583-604. http://dx.doi.org/10.2307/145686

Ravenhill, J. (1986). Africa's Continuing Crises: The Elusiveness of Development. In J. Ravenhil, Africa in Economic Crisis. London: Macmillan.

Ridder-Symoens, H. (1992). A History of the University in Europe, Universities in the Middle Ages (Vol. 1). Cambridge: Cambridge University Press.

Saint, W. S. (1992). Universities in Africa: Stratagies for Stablzation and Revitalization. Washington, DC: World Bank.

Samoff, J., \& Carrol, B. (2004). Conditions, Coalitions, and Influence: The World Bank and Higher Education in Africa. The Annual Conference of the Comparative and International Education Society. Salt Lake City.

Seepe, S. (2004). Towards an African Identity of Higher education. Pretoria: Vista University and Skotaville Media.

Teferra, D., \& Altbach, P. G. (2004). African Higher Education: Challenges for the 21st Century. Higher Education, 47(1), 21-50. http://dx.doi.org/10.1023/B:HIGH.0000009822.49980.30

UNESCO. (2010). TRENDS IN TERTIARY EDUCATION: SUB-SAHARAN AFRICA. UNESCO.

Varghese, N. (2009). Private sector as a partner in higher education development in Africa (ADEA-WGHE-AAU-IIEP Policy Brief). UNESCO.

World Bank. (1998). World development indicators 1998. Washington, DC: The World Bank.

World Bank. (2009). Accelerating Catch-up: Tertiary Education for Growth in Sub-Saharan Africa. Washington, DC: World Bank.

Yesufu, T. (1973). Creating the African University. London: Oxford University Press.

Zeleza, P. T. (2006, August 30). Beyond Afropessimism: Historical accounting of African Universities. Pambazuka News. 


\section{Copyrights}

Copyright for this article is retained by the author(s), with first publication rights granted to the journal.

This is an open-access article distributed under the terms and conditions of the Creative Commons Attribution license (http://creativecommons.org/licenses/by/3.0/). 